\title{
Yeast Rrp14p is a nucleolar protein involved in both ribosome biogenesis and cell polarity
}

\author{
HIROKO YAMADA, ${ }^{1}$ CHIHIRO HORIGOME, ${ }^{1}$ TAKAFUMI OKADA, CHIHARU SHIRAI, and KEIKO MIZUTA \\ Department of Biofunctional Science and Technology, Graduate School of Biosphere Science, Hiroshima University, Kagamiyama, \\ Higashi-Hiroshima 739-8528, Japan
}

\begin{abstract}
We previously cloned $R R P 14 / Y K L O 82 c$, whose product exhibits two-hybrid interaction with Ebp2p, a regulatory factor of assembly of $60 \mathrm{~S}$ ribosomal subunits. Depletion of Rrp14p results in shortage of $60 \mathrm{~S}$ ribosomal subunits and retardation of processing from $27 \mathrm{~S}$ pre-rRNA to $25 \mathrm{~S}$ rRNA. Furthermore, 35S pre-rRNA synthesis appears to decline in Rrp14p-depleted cells. Rrp14p interacts with regulatory factors of $60 \mathrm{~S}$ subunit assembly and also with Utp11p and Faf1p, which are regulatory factors required for assembly of $40 \mathrm{~S}$ ribosomal subunits. We propose that Rrp14p is involved in ribosome synthesis from the beginning of $35 \mathrm{~S}$ pre-rRNA synthesis to assembly of the $60 \mathrm{~S}$ ribosomal subunit. Disruption of RRP14 causes an extremely slow growth rate of the cell, a severe defect in ribosome synthesis, and a depolarized localization of cortical actin patches throughout the cell cycle. These results suggest that Rrp14p has dual functions in ribosome synthesis and polarized cell growth.
\end{abstract}

Keywords: ribosome assembly; pre-rRNA processing; cell polarity; RRP14; EBP2

\section{INTRODUCTION}

Yeast ribosomes are composed of four rRNAs and 79 ribosomal proteins. As yeast cells consume a great deal of energy to synthesize ribosomes, production of the components is highly regulated in response to environmental changes and intracellular insults (see, for example, Warner and Udem 1972; Mizuta and Warner 1994; for review, see Warner 1999). Three mature (25S, 18S, and 5.8S) rRNAs are synthesized as a long precursor, 35S pre-rRNA, in the nucleolus (for review, see Woolford and Warner 1991). The $90 \mathrm{~S}$ preribosome particle contains 35S pre-rRNA, ribosomal proteins, small subunit (SSU) processome, and other nonribosomal proteins, most of which are required for $40 \mathrm{~S}$ subunit assembly (Grandi et al. 2002). The 35S pre-rRNA is cleaved at sites $A_{0}, A_{1}$, and $A_{2}$, and the $90 \mathrm{~S}$ complex is converted to precursors of $40 \mathrm{~S}$ and $60 \mathrm{~S}$ subunits (see Fig. 3A, below) (for review, see Kressler et al. 1999; Venema and Tollervey 1999). A combination of TAP purification and proteome analysis has revealed that about 200 nonribo-

\footnotetext{
${ }^{1}$ These authors contributed equally to this work.

Reprint requests to: Keiko Mizuta, Department of Biofunctional Science and Technology, Graduate School of Biosphere Science, Hiroshima University, 1-4-4, Kagamiyama, Higashi-Hiroshima 739-8528, Japan; E-mail: kei7mizuta@hiroshima-u.ac.jp; Fax: 81824247923.

Article published online ahead of print. Article and publication date are at http://www.rnajournal.org/cgi/doi/10.1261/rna.553807.
}

somal proteins are involved for pre-rRNA processing and assembly of the $60 \mathrm{~S}$ and $40 \mathrm{~S}$ subunits (e.g., Hampichamchai et al. 2001; Bassler et al. 2001; for review, see Warner 2001; Tschochner and Hurt 2003). However, it remains to be elucidated how these regulatory factors regulate the assembly. We previously demonstrated that Ebp2p is one of the regulatory factors essential for maturation of $25 \mathrm{~S}$ rRNA and assembly of $60 \mathrm{~S}$ ribosomal subunits (Tsujii et al. 2000). We cloned RRP14/YKL082c in a two-hybrid screen by using EBP2 as bait (Shirai et al. 2004). Rrp14p shares an amino acid sequence with the mouse SURF-6 gene product, and both Rrp14p and the mouse homolog are localized to the nucleolus (Magoulas and Fried 1996; Drees et al. 2001; Polzikov et al. 2005). The mammalian SURF-6 gene was discovered as the sixth member of the tightly clustered mammalian Surfeit locus (Magoulas and Fried 1996).

Yeast Rrp14p was found in the fractions that were copurified with Ssf1p-TAP (Fatica et al. 2002) and Rrp1pTAP (Horsey et al. 2004), both of which are regulatory proteins of $60 \mathrm{~S}$ ribosomal subunit biogenesis. However, it remains to be elucidated whether Rrp14p is a bona fide factor for ribosome synthesis. Furthermore, it was demonstrated that Rrp14p has two-hybrid interactions with Zds2p, Giclp, Gic2p, and Bud8p, which are related to cell polarity (Drees et al. 2001).

It was reported that RRP14 is essential for growth in systematic analysis (Winzeler et al. 1999). In this paper, 
however, we find that the $\operatorname{rrp} 14 \Delta$ strain is viable with slow growth rate. We report that the $\operatorname{rrp} 14 \Delta$ strain has a severe defect in ribosome synthesis and exhibits aberrant cell polarity and cell morphology. This is the first report showing that a regulatory factor of ribosome synthesis has an important role in the cell polarity derived from actin localization.

\section{RESULTS}

\section{Rrp14p is enriched in the nucleolus}

In order to ascertain the subcellular localization of Rrp14p, we constructed a strain KM1419 expressing Rrp14p fused with Yellow fluorescent protein (YFP) at the $\mathrm{N}$ terminus. The integrated YFP-RRP14 could complement the growth defect of the rrp14 null mutation (see below), indicating that the construct is biologically functional. The subcellular localization of YFP-Rrp14p was analyzed by fluorescence microscopy. Nop1p-Cyan fluorescent protein (CFP), used as a marker for the nucleolus, was detected in the region adjacent to the DAPIstained nucleoplasm. The signal of YFP-Rrp14p was seen in the same region as Noplp-CFP (data not shown), which is consistent with a previous observation that Rrp14p is primarily localized in the nucleolus (Drees et al. 2001). Furthermore, a weak signal of YFP-Rrp14p was also seen in the nucleoplasm. These results suggest that Rrp14p functions mainly in the nucleolus and also in the nucleoplasm.

\section{Depletion of Rrp14p results in shortage of 605 ribosomal subunits}

In order to achieve conditional expression of $R R P 14$, we constructed the KM1411 strain in which the chromosomal $R R P 14$ gene was disrupted and expression of myc-Rrp14p was driven by the galactose-inducible and glucose-repressible GAL1 promoter. When KM1411 was shifted from galactose to glucose medium, the growth rate of the cell was temporarily increased followed by decline; the growth was severely impeded $24 \mathrm{~h}$ after the shift (Fig. 1A). Western blot analysis using anti-myc antibodies revealed that mycRrp14p was overproduced when the KM1411 strain was cultured in galactose medium compared to the level in the KM1412 strain in which expression of MYC-RRP14 was controlled by the RRP14 promoter (Fig. 1B, lanes 1,7). The expression level of myc-Rrp14p was decreased after the shift of the cells from galactose to glucose medium; $6 \mathrm{~h}$ after the shift, the expression level of myc-Rrp14p was similar to the wild-type level and significantly decreased $12 \mathrm{~h}$ after the shift (Fig. 1B).

The effect of depletion of Rrp14p on ribosome biogenesis was examined by using the KM1411 strain. We performed sucrose density gradient ultracentrifugation using cell extracts with equal $A_{260}$ units. The polysome profile of the strain KM1411 cultured in glucose medium for $18 \mathrm{~h}$ clearly revealed that the level of $60 \mathrm{~S}$ subunits was reduced in the Rrp14p-depleted cells; 60S subunits, $80 \mathrm{~S}$ monosomes, and polysomes decreased, and half-mer polysomes that contain $43 \mathrm{~S}$ initiation complexes stalled at the AUG start codon appeared (Fig. 2A). These results indicate that Rrp $14 \mathrm{p}$ is required for $60 \mathrm{~S}$ ribosomal subunit assembly. Nevertheless, it is noteworthy that only a small amount of $40 \mathrm{~S}$ subunits accumulated, suggesting that Rrp14p is also required for assembly and/or maintenance of $40 \mathrm{~S}$ ribosomal subunits.

\section{RRP14 is required for production of $25 S$ rRNA and also $18 \mathrm{~S}$ rRNA}

We performed $\left[\right.$ methyl $\left.^{3} \mathrm{H}\right]$ methionine pulse-chase analysis to investigate whether the depletion of Rrp14p caused a defect in pre-rRNA processing. The $35 \mathrm{~S}$ pre-rRNA, the longest detectable precursor, is cleaved to $27 \mathrm{~S}$ and the $20 \mathrm{~S}$ pre-rRNAs, which are further processed to the mature 25S and $18 \mathrm{~S}$ rRNAs, respectively (Fig. 3A). The cells were pulsed with $\left[\right.$ methyl- $\left.{ }^{3} \mathrm{H}\right]$ methionine for $3 \mathrm{~min}$. In wildtype cells, most precursor rRNAs were processed to $25 \mathrm{~S}$ and $18 \mathrm{~S}$ after a 3-min chase (Fig. 3B, lanes 1-4). On the other hand, when the KM1411 (GAL-RRP14) strain was cultured in glucose medium for $18 \mathrm{~h}$, the processing rate of the $27 \mathrm{~S}$ pre-rRNA to $25 \mathrm{~S}$ rRNA appeared to be slower and less 

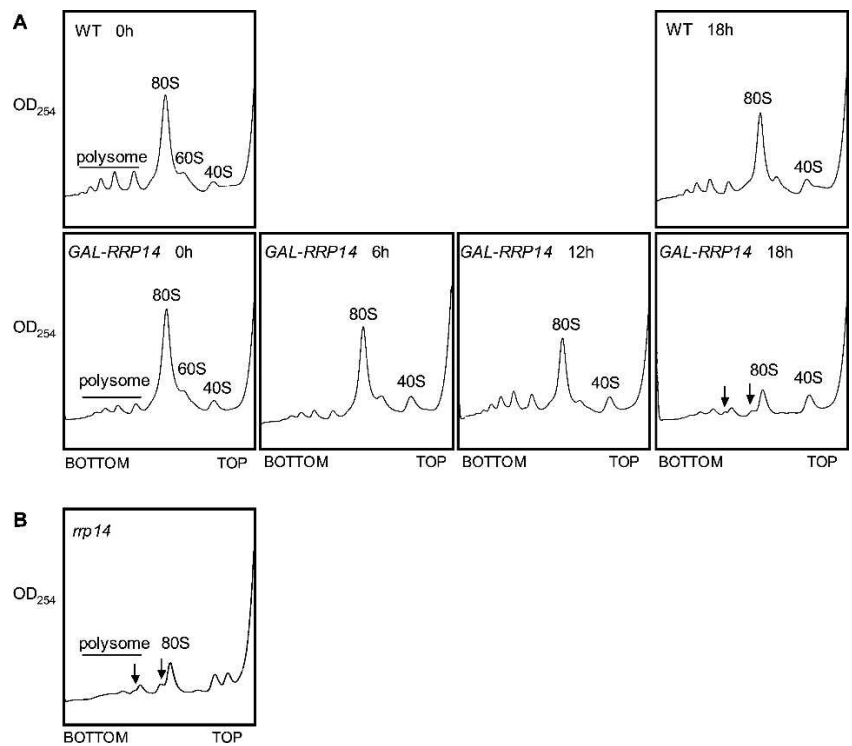

FIGURE 2. Rrp14p depletion causes a defect in assembly of $60 \mathrm{~S}$ ribosomal subunits. $(A)$ The polysome profiles from W303-1A transformed with pRS414 (WT) and KM1411 (GAL1-RRP14) strains cultured at $30^{\circ} \mathrm{C}$ in SCGal, shifted to SC, and cultured for the indicated time. (B) The polysome profiles from the KM1421 ( rrp14A) strain cells cultured at $30^{\circ} \mathrm{C}$ in SC. The positions of $40 \mathrm{~S}, 60 \mathrm{~S}$, and $80 \mathrm{~S}$ ribosomal particles, and polysomes are indicated. Arrows indicate half-mer polysomes.

amount of $25 \mathrm{~S}$ rRNA was produced than that of the wildtype cells (Fig. 3B, lanes 5-8). Moreover, although the maturation from the $20 \mathrm{~S}$ pre-rRNA to $18 \mathrm{~S}$ rRNA was not significantly slower, a lesser amount of the mature $18 \mathrm{~S}$ rRNA was produced in the Rrp14p-depleted cells compared to the wild-type cells (Fig. 3B). It is noteworthy that the incorporation of radioactivity of $\left[\right.$ methyl $\left.-{ }^{3} \mathrm{H}\right]$ methionine into RNA reduced when Rrp14p was depleted; the relative incorporations were $26 \%, 25 \%, 22 \%$, and $31 \%$ after chase for $0,3,10$, and $20 \mathrm{~min}$, respectively, in the Rrp14pdepleted cells compared to wild-type cells (data not shown). These data indicate that newly synthesized prerRNA and processed rRNA appear rather stable for at least $20 \mathrm{~min}$ in the Rrp14p-depleted cells. These results suggest that when Rrp14p was depleted, transcription of pre-rRNA declined, and maturation of $25 \mathrm{~S}$ rRNA was delayed.

We next performed Northern analysis showing the steady-state levels of mature rRNAs and pre-rRNAs in the wild-type and KM1411(GAL-RRP14) strains cultured in galactose medium and after the shift to glucose medium for various periods of time (Fig. 4A). As the level of total RNA in the cell declined when Rrp14p was depleted, RNA samples corresponding to the equal $\mathrm{OD}_{600}$ units of cells were compared. When the wild-type cells were shifted from galactose medium to glucose medium, both $35 \mathrm{~S}$ pre-rRNA and mature rRNAs increased and the levels were maintained $24 \mathrm{~h}$ after shifting to glucose medium, consistent with our previous reports (Tsuno et al. 2000; Tsujii et al.
2000). Following the transfer of the GAL1-RRP14 strain to glucose medium, the steady-state level of both 25S rRNA and $18 \mathrm{~S}$ rRNA temporarily increased and then reduced with time of incubation in glucose medium [Fig. 4A(a)]. Compared to the level of RNAs in the wild-type cells $24 \mathrm{~h}$ after shifting to glucose medium, the Rrp14p-depleted cells have smaller amounts of $35 \mathrm{~S}$ pre-rRNA and mature 25S, $18 \mathrm{~S}$, and $5.8 \mathrm{~S}$ rRNAs [Fig. $4 \mathrm{~A}(\mathrm{a})$, lanes $3,7,4 \mathrm{~A}(\mathrm{~b})$, lanes $2,6]$, whereas the levels of $5 S$ rRNA and tRNA are not significantly declined [Fig. 4A(b), lanes 2,6]. 23S RNA, which is produced by the cleavage of $35 \mathrm{~S}$ at a site $\mathrm{A}_{3}$ without the cleavages at sites $A_{0}, A_{1}$, or $A_{2}$, was not accumulated in the Rrp14p-depleted cells [Fig. 4A(a)]. This suggests that processing of $35 \mathrm{~S}$ at $A_{0}, A_{1}$, or $A_{2}$ is not delayed. These results suggest that the synthesis of $35 \mathrm{~S}$ pre-rRNA declines when Rrp14p is depleted, consistent with the results of the $\left[\right.$ methyl $\left.-{ }^{3} \mathrm{H}\right]$ methionine pulse-chase analysis.

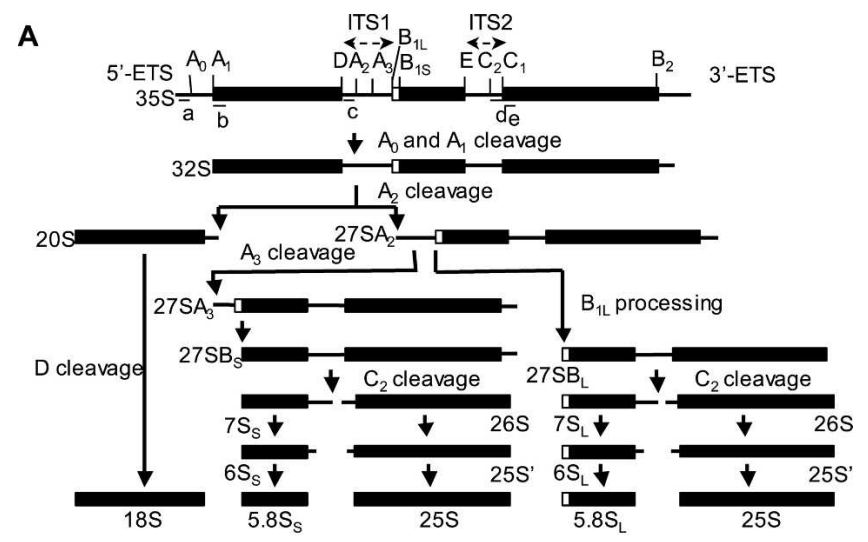

B

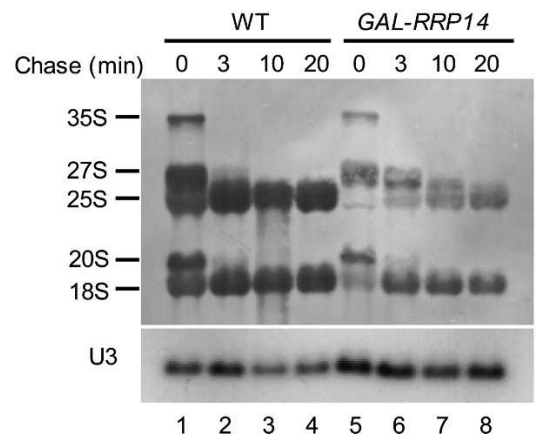

FIGURE 3. Rrp14p depletion causes a defect in $25 \mathrm{~S}$ rRNA maturation. (A) The processing pathway of $35 \mathrm{~S}$ pre-rRNA to the mature rRNAs in S. cerevisiae. Northern probes (a), (b), (c), (d), and (e) used in Figure 4 are shown. $(B)$ Pulse-chase analysis of rRNA synthesis in Rrp14p-depleted cells. W303-1A transformed with pRS414 (WT, lanes 1-4) and KM1411 (GAL1-RRP14 lanes 5-8) were cultured at $30^{\circ} \mathrm{C}$ in SCGal-Met and Trp, shifted to SC-Met and Trp, and cultured for $18 \mathrm{~h}$. Each culture was pulsed with $\left[\right.$ methyl $\left.^{3} \mathrm{H}\right]$ methionine for $3 \mathrm{~min}$ and chased with nonradioactive methionine for the indicated times. Total RNA prepared from each sample was analyzed by electrophoresis and blotted to a membrane. The lower part of the membrane was probed for U3 snoRNA as a loading marker. 
A

(a)

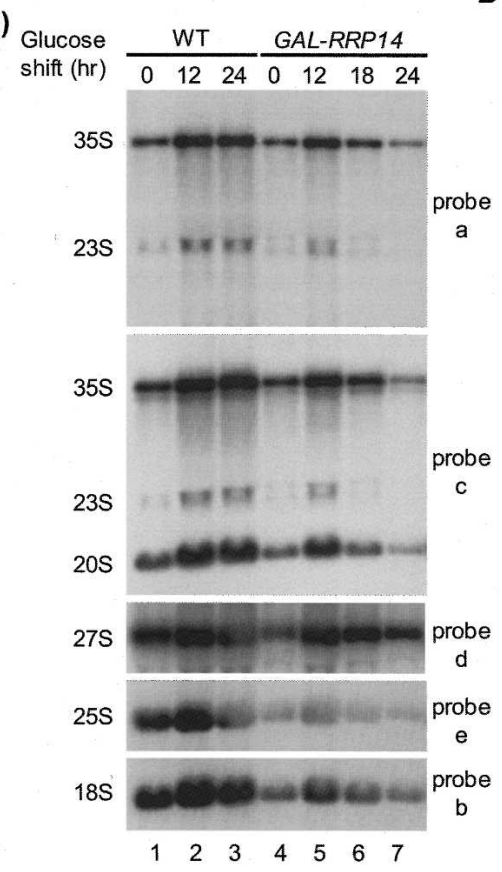

(b)

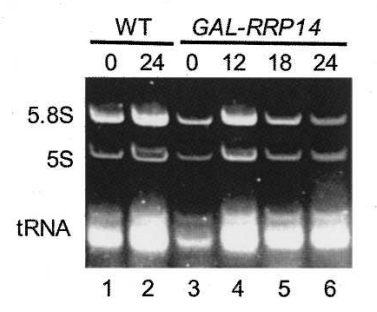

(a)

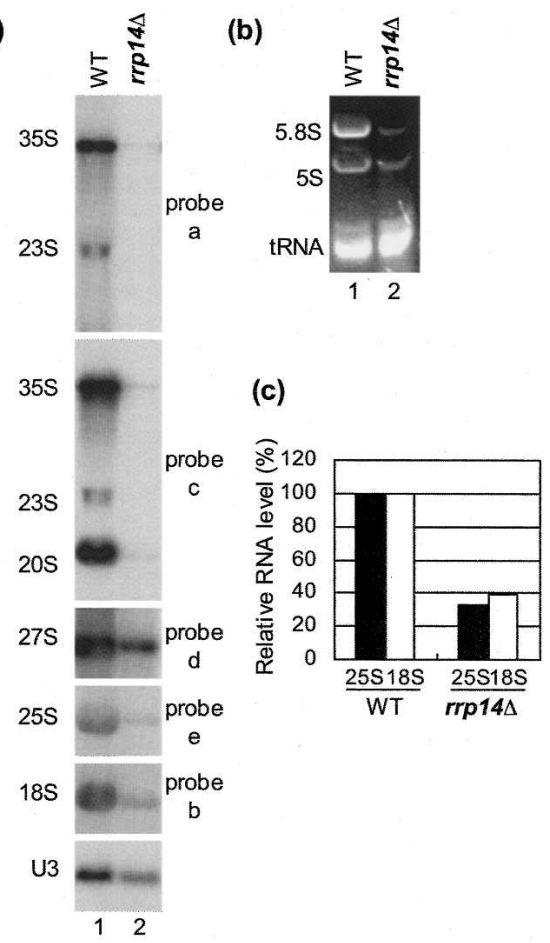

FIGURE 4. Northern analysis for steady-state level of rRNAs. (A) W303-1A transformed with pRS414 (WT) and KM1411 (GAL1-RRP14) cultured at $30^{\circ} \mathrm{C}$ in SCGal were shifted to SC and cultured for the indicated times. Total RNA corresponding to $0.5 \mathrm{OD}_{600}$ of cells was used for Northern blot analysis. $[A(a)]$ Northern blot analysis was carried out using ${ }^{32}$ P-labeled DNA probes a, b, c, d, and e, which are shown in Figure 3A. $[A(b)]$ Ethidium bromide staining of a denaturing $6 \%$ polyacrylamide/8M urea gel is shown. (B) W303-1A (WT) and KM1422 (rrp14A) cultured at $30^{\circ} \mathrm{C}$ in SC medium. Total RNA corresponding to $0.5 \mathrm{OD}_{600}$ of cells was used for Northern blot analysis. $[B(a)]$ Northern blot analysis was carried out using ${ }^{32} \mathrm{P}$-labeled DNA probes $\mathrm{a}, \mathrm{b}, \mathrm{c}, \mathrm{d}$, and e, and a probe for U3 snoRNA. $[B(b)]$ Ethidium bromide staining of a denaturing $6 \%$ polyacrylamide/8M urea gel is shown. $[A(c)]$ Mature $25 \mathrm{~S}$ and $18 \mathrm{~S}$ rRNA levels shown in $B(a)$ were quantified using BAS-2000 and BAS-1800 (Fuji Photo Film Co.), normalized with the U3 level, and the ratio of the radioactivity value of the $\operatorname{rrp} 14 \Delta$ strain per that of wild-type strain serves as the percent.

\section{The $\operatorname{rrp} 14 \Delta$ cells grow extremely slowly with a defect in ribosome synthesis}

An $R R P 14$-null allele was created by replacing one of the RRP14 ORF of the diploid strain, W303, with the HIS3 gene followed by tetrad analysis. As the $3^{\prime}$-end region of the RRP14 ORF overlaps the YKL083W ORF, we deleted 590 base-pairs (bp) from the $60 \mathrm{bp}$ downstream initiation codon of the RRP14 ORF to avoid deleting the YKL083W ORF (Fig. 5A). PCR analysis of chromosomal DNA isolated from a candidate of W303 rrp14 $/$ / demonstrated that the resultant diploid cell carried one intact RRP14 gene and one disrupted by insertion of HIS3 (data not shown).
Twenty-eight tetrads from the rrp144/+ diploid were dissected. After growing for $3 \mathrm{~d}$ at $25^{\circ} \mathrm{C}$, only two colonies were observed from each set of tetrad, and after longer growing, the tetrads yielded two large colonies and two small colonies (Fig. 5B). The cells from the small colonies were $\mathrm{His}^{+}$, indicating that the $\operatorname{rrp} 14 \Delta$ cells grow extremely slowly. The rrp14A cells grow with doubling times of $\sim 15 \mathrm{~h}$ and $\sim 11 \mathrm{~h}$ in liquid $\mathrm{SC}$ medium at $25^{\circ} \mathrm{C}$ and $30^{\circ} \mathrm{C}$, respectively. As RRP14 was reported to be essential for growth in systematic analysis (Winzeler et al. 1999), we constructed the rrp14A strain in another background. The rrp14A strain derived from BY4741 was also viable with a similar doubling time to rrp14s derived from W303 (data not shown).

In order to examine if $\operatorname{rrp} 14 \Delta$ caused a defect in ribosome synthesis, we performed sucrose density gradient ultracentrifugation and Northern analysis. The polysome profile of rrp14A cells shows the appearance of half-mer peaks, indicating that $\operatorname{rrp} 14 \Delta$ results in the shortage of $60 \mathrm{~S}$ subunits (Fig. 2B). Northern analysis revealed that the rrp14A cells have only a small amount of mature 25S, 18S, and 5.8S rRNAs, and the level of $35 \mathrm{~S}$ pre-rRNA was also significantly declined. The $\operatorname{rrp} 14 \Delta$ cells have similar levels of both $5 \mathrm{~S}$ rRNA and tRNA to that in wild-type cells (Fig. 4B).

To examine whether the transcriptional activity of rDNA is declined in the $\operatorname{rrp} 14 \Delta$ strain, we performed run-on transcription analysis (Fig. 6). Yeast cells were chilled rapidly, permeabilized, and incubated with $\alpha-{ }^{32} \mathrm{P}$-UTP to elongate previously initiated transcripts. The amount of RNA synthesized was measured by hybridization of the radiolabeled RNA to slot blots containing plasmids with the DNA sequences (Fig. 6A) representing transcribed portions of the 35S rRNA (5'ETS, 25S) and 5S rRNA genes. Disruption of RRP14 resulted in greatly reduced transcription of $35 \mathrm{~S}$ rRNA genes (Fig. 6B). In contrast, 5S rRNA genes appeared to be transcribed in $\operatorname{rrp} 14 \Delta$ cells at a similar rate to that in wild-type cells (Fig. 6B).

Taken together, it is suggested that Rrp14p is required for both $35 \mathrm{~S}$ pre-rRNA synthesis and 25S rRNA maturation/60S subunit assembly. 
A

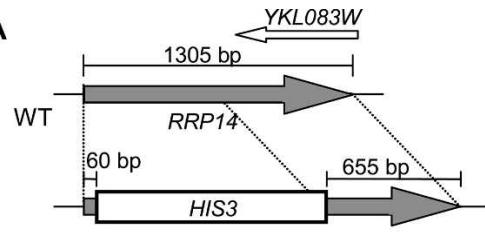

$\operatorname{rrp} 14::$ HIS3

B

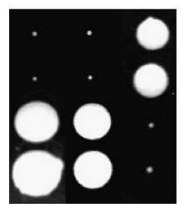

FIGURE 5. The $r r p 14 \Delta$ cells grow extremely slowly. (A) Construction of rrp14A with the HIS3 gene. (B) Tetrad analysis of the RRP14/ $\operatorname{rrp} 14 \Delta \therefore$ HIS3 strain. Three sets of tetrads were cultured on a YPD plate at $25^{\circ} \mathrm{C}$ for $12 \mathrm{~d}$.

\section{Two-hybrid interactions of Rrp14p with a ribosomal protein and regulatory factors of ribosome synthesis}

$R R P 14$ was previously isolated in two-hybrid screening by using EBP2 as bait. In the screen, we found that Ebp2p interacts with Utp11p and Faflp that are required for $40 \mathrm{~S}$ subunit assembly, and ribosomal protein Rps16p besides several factors required for $60 \mathrm{~S}$ subunit assembly (Shirai et al. 2004; for the nomenclature of ribosomal proteins, see Mager et al. 1997). Each combination of Utp11p, Faflp, and Rps16p exhibited a positive two-hybrid interaction (Shirai et al. 2004). We proposed that Ebp2p associates with Utp11p, Faflp, and Rps16p in the 90S particle and remains in the $60 \mathrm{~S}$ preribosomal subunit after the $90 \mathrm{~S}$ particle is converted into two preribosomal subunits (Shirai et al. 2004). Thus, in this study, we tested to see if Rrp14p interacts with these factors. Interestingly, Rrp14p exhibited a two-hybrid interaction with Utp11p, Faf1p, and Rps16p (Fig. 7) as well as the factors that are required for $60 \mathrm{~S}$ subunit assembly such as Loc1p, Nop12p, and Dbp9 (data not shown). These results suggest that Rrp14p, like Ebp2p, associates with the $90 \mathrm{~S}$ preribosomal particle and functions in pre-60S ribosomal subunits after the $90 \mathrm{~S}$ particle is divided into two preribosomal subunits.

\section{The $\operatorname{rrp14} \Delta$ cells exhibit aberrant morphology}

Microscopic observation revealed that $\operatorname{rrp} 14 \Delta$ resulted in aberrant morphological cells. Chained cells and multibudded cells were observed in several percentages of the $\operatorname{rrp} 14 \Delta$ cells even after brief sonication (Fig. 8A). Staining with 4',6-diamidino-2-phenylindole (DAPI) showed that nuclear division had occurred without cell division (Fig. $8 \mathrm{~B})$. These data suggest that some cells initiate a new round of cell cycle in the absence of cell separation. Similar phenotypes were observed in the rrp144 cells in the background of BY4741 (data not shown).

\section{The $\operatorname{rrp} 14 \Delta$ cells has a defect in cell polarity}

As cell separation is intimately related to cell polarity, we examined the distribution of cortical actin patches in the rrp14 $\Delta$ cells by using CalMorph, an image processing program that automatically recognizes budding yeast cell morphology (Ohtani et al. 2004; Saito et al. 2004, 2005). CalMorph can extract morphological data directly from fluorescence microscopic images of the budding yeast cell wall, actin, and nucleus stained with fluorescein isothiocyanate-Concanavalin A (FITC-ConA), rhodamine-phalloidin, and DAPI, and can generate quantitative data about yeast cell shape, nuclear shape and location, and actin distribution. Logarithmically growing cells of the wild-type and $\operatorname{rrp} 14 \Delta$ strains were collected, stained, and photographed, and the images were processed with CalMorph. Bud index and actin distribution are shown in Table 1. The rrp144 strain shows an increased proportion of unbudded cells. The wild-type cells exhibited a polarized localization of cortical actin patches; $89 \%$ of small-budded, $87 \%$ of medium-budded, and more than a half unbudded and large-budded wild-type cells showed a staining pattern of cortical actin patches toward the bud tips (pattern $c$ in Table 1) or throughout bud (Table 1, pattern d). In contrast, a large percentage of the $\operatorname{rrp} 14 \Delta$ cells exhibited a depolarized pattern throughout the cell cycle; 95\%, 67\%, $57 \%$, and $65 \%$ of unbudded, small-, medium-, and largebudded $\operatorname{rrp14\Delta }$ cells, respectively, showed a nonpolarized

A

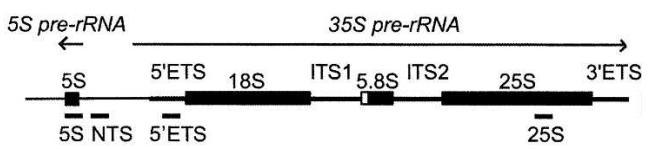

B (a)

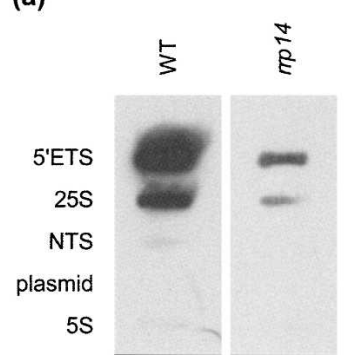

(b)

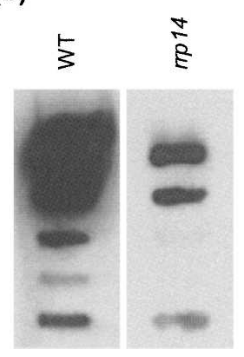

FIGURE 6. Run-on transcription assays. $(A)$ The rDNA transcription unit. RNA polymerase I transcribes the $35 \mathrm{~S}$ primary rRNA transcript, whereas RNA polymerase III transcribes the 5S rRNA in the opposite direction. PCR products corresponding to the indicated segments of the $5^{\prime}$ external transcribed spacer (5'ETS), the $25 \mathrm{~S}$ rRNA, NTS, and the $5 \mathrm{~S}$ rRNA were cloned into the pTOPO plasmid. (B) Transcription run-on analysis. The wild-type and $\operatorname{rrp} 14 \Delta$ strains were cultured, permeabilized, and exposed to $\alpha-{ }^{32} \mathrm{P}$-UTP for $10 \mathrm{~min}$. RNA was extracted and hybridized to the plasmids slot-blotted onto Nitran membrane. Autoradiograph $[B(b)]$ is exposed for longer than autoradiograph $[B(a)]$. 


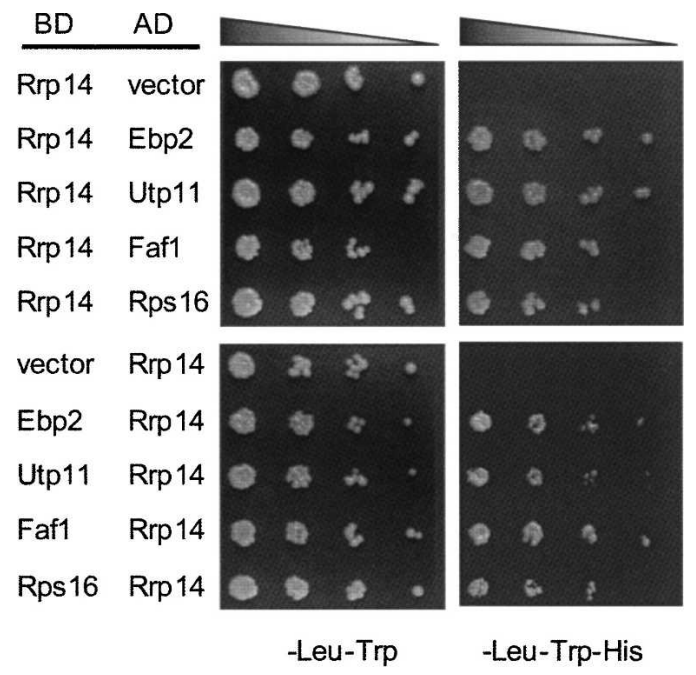

FIGURE 7. Rrp14p interacts with Utp11p, Faflp, and Rps16p. Protein-protein interactions were analyzed by the yeast two-hybrid system. Fivefold serial dilutions of cultures of L40 strain cells transformed with lexA binding domain-fused (BD) and Gal4p activation domain-fused (AD) genes were plated on SC-Trp, Leu, and SC-Trp, Leu, His. As the empty vector containing lexA binding domain (pBTM116) exhibits a background level of expression, $1 \mathrm{mM} \mathrm{3-}$ aminotriazole was added to a SC-Trp, Leu, His plate for the lower five combinations.

localization of cortical actin patches spreading over the entire mother cell and bud (Table 1, patterns a and e). The result indicates that loss of Rrp14p function results in depolarized cell growth.

During division by budding, yeast cells polarize toward division sites that are chosen based on cell type (for review, see Chant 1999). Haploid cells exhibit an axial budding pattern in which mother and daughter cells bud immediately adjacent to their previous sites of cell division. Cells that are defective in actin-based polarized morphogenesis often display errors in bud site selection. Furthermore, Giclp and Gic2p that interact with Rrp14p were suggested to be required for axial bud site selection (Chen et al. 1997). Thus, we examined the budding patterns of haploid wildtype and $\operatorname{rrp} 14 \Delta$ cells that contained three or more calcofluor-stained bud scars. For wild-type haploids, $99.3 \%$ of the cells displayed an axial budding pattern, whereas only $4.2 \%$ of haploid $\operatorname{rrp} 14 \Delta$ cells showed an axial pattern (Fig. 9; Table 2); $92.9 \%$ and $2.9 \%$ of $\operatorname{rrp} 14 \Delta$ cells exhibited random and bipolar patterns, respectively. These results indicates that polarity for bud site selection is completely lost in the rrp14A cells.

\section{DISCUSSION}

We demonstrated in this paper that Rrp14p has dual functions in ribosome synthesis and cell division. We obtained viable $\operatorname{rrp} 14 \Delta$ cells with a slow growth rate in the background of both W303 and BY4741 strains. It was reported that RRP14 is necessary for viability from knockout yeast mutants (Winzeler et al. 1999). There are two possibilities for the discrepancy. In the genome-wide analysis, the positions of the deletions were not adjusted, even though $10 \%$ of ORFs in Saccharomyces cerevisiae overlap one another. As the RRP14 ORF overlaps the $Y K L 083 W$ ORF, which is also categorized as an essential gene in the same analysis, deletion of YKL083W might affect the viability of the $\operatorname{rrp} 14 \Delta$ strain. A second possibility is that it could be considered to be inviable because of its extremely slow growth. As we delete $590 \mathrm{bp}$ from the $60 \mathrm{bp}$ downstream initiation codon of the RRP14 ORF and inserted HIS3, it is unlikely that functional proteins are expressed from the remaining region of the RRP14 ORF. Using the $r r p 14 \Delta$ strain, in this paper, we demonstrate that the function of Rrp14p is necessary for cell polarity derived from polarity of the actin cytoskeleton.

\section{Rrp14p has a role in ribosome biogenesis}

RRP14 was previously cloned in two-hybrid screening by using EBP2 as bait (Shirai et al. 2004). Ebp2p is essential for $25 S$ rRNA maturation and 60S subunit assembly. Previous reports demonstrated that Rrp14p was copurified with Ssf1p-TAP (Fatica et al. 2002) and with Rrplp-TAP (Horsey et al. 2004). As expected from these results, we confirmed that Rrp14p has an important role in ribosome synthesis. In the polysome profile, it appears that Rrp14p is required for the $60 \mathrm{~S}$ subunit assembly. $\left[\right.$ Methyl- $\left.{ }^{3} \mathrm{H}\right]$ methionine pulse-chase analysis reveals delay of processing from $27 \mathrm{~S}$ to $25 \mathrm{~S}$ rRNA in the Rrp14p-depleted strain, indicating that Rrp14p also has an important function in 25S rRNA maturation, consistent with the polysome profile and
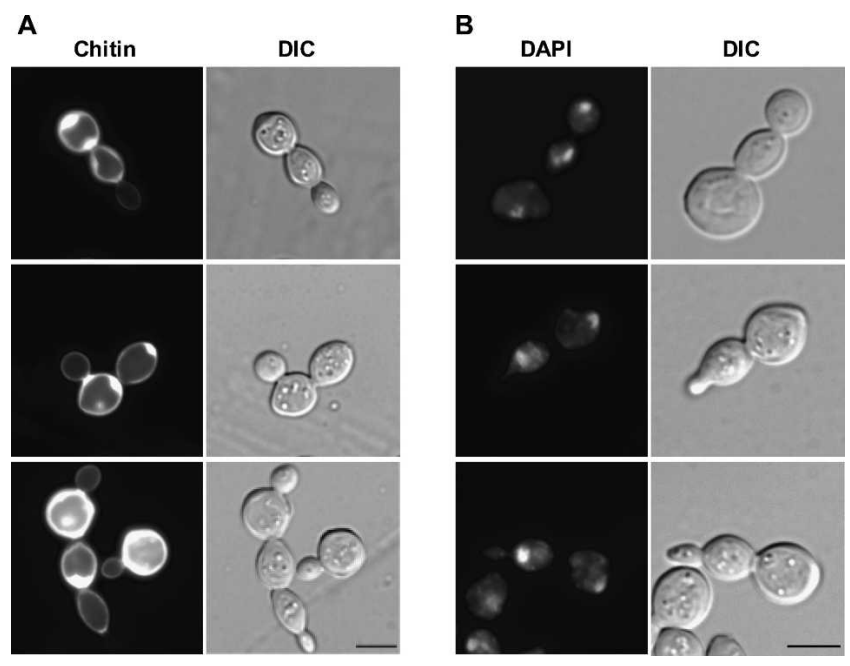

FIGURE 8. The rrp14A cells exhibit aberrant cell morphology. (A) Calcofluor staining and cell morphology (DIC) of the KM1422 (rrp14A) cells. (B) DAPI staining and cell morphology of the KM1422 (rrp14A) cells. Bars indicate $5 \mu \mathrm{m}$. 
TABLE 1. The rrp14A cells exhibit an abnormality in the distribution of cortical actin patches

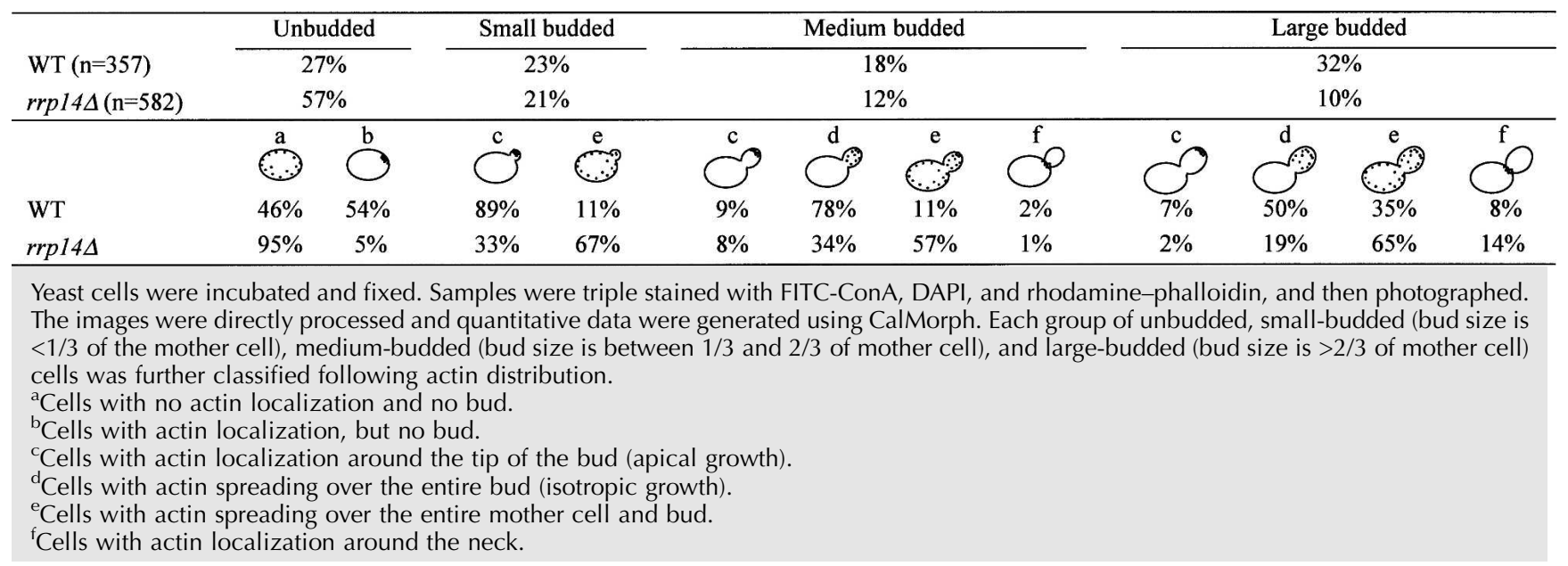

suggesting the shortage of $60 \mathrm{~S}$ subunits. The defect of the Rrp14p depletion, however, is not restricted in 25S rRNA maturation/60S subunit assembly. $\left[\right.$ Methyl $\left.-{ }^{3} \mathrm{H}\right]$ methionine pulse-chase analysis also suggests that pre-rRNA transcription declines and consequently lesser amounts of $25 \mathrm{~S}$ and $18 \mathrm{~S}$ rRNAs are produced in the Rrp14p-depleted strain. Run-on transcription analysis confirms that Rrp14p is required for $\mathrm{rDNA}$ transcription.

Rrp14p has a SURF-6 domain that is evolutionarily conserved from human to yeast. The domain is localized in the carboxyl terminus of all eukaryotic proteins, and has an average length of 191 amino acids with an average residue identity of $36 \%$ between different species. It was demonstrated that SURF-6 binds to both DNA and RNA in vitro (Magoulas et al. 1998). It is possible that Rrp14p binds to the promoter region of rDNA, affects its transcription, and subsequently binds to the $90 \mathrm{~S}$ preribosomal particle to function in pre-rRNA processing and ribosomal subunit assembly. Ribosomal RNA transcription and preRNA processing are coordinated via specific components of the small subunit processome that associates with $35 \mathrm{~S}$ prerRNA (Gallagher et al. 2004). In this study, we find that Rrp14p interacts with Utp11p and Faf1p. It was demonstrated that Utp11p is a component of the SSU processome and Faflp associates with a large number of components of SSU (Dragon et al. 2002; Rempola et al. 2006). Interestingly, Faflp was categorized as a middle-strength transcription activator in systematic analysis using the yeast onehybrid system (Titz et al. 2006). We speculate that Rrp14p is specifically involved in transcription of rDNA, processing of pre rRNA, and 60S subunit assembly.

\section{Rrp14p has a role in cell polarity}

We demonstrate in this paper that Rrp14p has an important role in cell polarity. The data were automatically and quantitatively analyzed with the CalMorph program, which was used for the Saccharomyces cerevisiae Morphological Database (SCMD; http://scmd.gi.k.u-tokyo.ac.jp/) (Ohtani et al. 2004; Saito et al. 2004, 2005). In S. cerevisiae, following the selection of a bud site, all growth was directed into the bud. This polarized growth of the budding yeast derives from the polarity of the actin cytoskeleton; at the last step of the cell cycle, cytokinesis is accomplished by the concerted action of actomyosin ring contraction and septum formation, followed by cell separation of the daughter cell from the mother cell by the degradation of the septum. Chitinases and glucanases were transported to the bud neck and degrade the septum (Cabib et al. 2001; Baladron et al. 2002). The establishment and maintenance of a polarized actin cytoskeleton is necessary for polarized secretion. It is possible that a defect of $\operatorname{rrp} 14 \Delta$ in cell polarity causes mislocalization of the enzymes, which causes a defect in cell separation. Our results are consistent with large-scale two-hybrid data showing that Rrp14p interacts with Giclp, Gic2p, and Zds2p (Drees et al. 2001). Gic1p and Gic2p, which share sequence similarity, are suggested to be involved in initiation of budding and cellular polarization via interaction with the Rho family

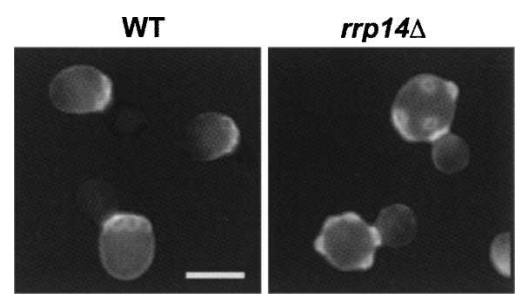

FIGURE 9. The $\operatorname{rrp} 14 \Delta$ cells lose polarity for bud site selection. BY4741(WT) and KM1431 (rrp14A) haploid cells were grown to a midlogarithmic phase, sonicated for cell separation, and stained with Calcofluor White to visualize bud scars. 
TABLE 2. The $\operatorname{rrp} 14 \Delta$ cells exhibit an abnormality in budding pattern

\begin{tabular}{lrcr}
\hline & Axial (\%) & Bipolar (\%) & \multicolumn{1}{c}{ Random (\%) } \\
\hline WT & $99.3 \pm 0.7$ & $0.0 \pm 0.0$ & $0.7 \pm 0.7$ \\
rrp144 & $4.2 \pm 0.4$ & $2.9 \pm 0.3$ & $92.9 \pm 0.2$ \\
\hline
\end{tabular}

BY4741(WT) and KM1431 (rrp144) haploid cells were stained with Calcofluor White as shown in Figure 9. For each sample, a minimum of 100 cells was counted in two independent experiments.

GTPase Cdc42p (Chen et al. 1997). It was suggested that $\mathrm{Zds} 2 \mathrm{p}$ is a negative regulator of Cdc42p, while it appears to be involved in multiple cellular events ( $\mathrm{Bi}$ and Pringle 1996).

\section{Connection between ribosome synthesis and cell cycle}

While we were preparing the manuscript, Oeffinger et al. (2007) reported that Rrp14p has dual functions, ribosome synthesis and positioning of the mitotic spindle. We find independently that Rrp14p has dual functions in ribosome synthesis and cell polarity. It is important to note that in our hands pre-rRNA synthesis declined when Rrp14p was depleted. This suggests that Rrp14p is involved in not only $60 \mathrm{~S}$ subunit assembly but also in transcription of rDNA. We also found that cortical actin patches were depolarized throughout the cell cycle and the establishment of bud sites was compromised in the rrp14 $\Delta$ cells. The cell morphology

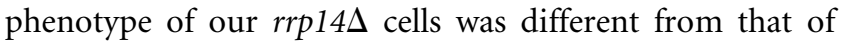
Rrp14p depleted cells found by Oeffinger et al. (2007); we observed that nuclei divide in the $\operatorname{rrp} 14 \Delta$ strain, whereas they demonstrated that upon depletion of Rrp14, nuclei do not divide but cells form buds. The difference might be due to strain differences and/or different experimental conditions such as deletion or depletion, and asynchronicity or synchronicity. Cell polarity is related to various cell cycle events including mitotic exit and cytokinesis. It is possible that a defect of cell polarity may result in various phenotypes. As polarized growth and intracellular polarity in the budding yeast are derived from actin polarization, depolarization of actin might be a fundamental cause of various phenotypes such as the abnormal cell morphology of the $\operatorname{rrp} 14 \Delta$ cells (Fig. 8) and incorrect positioning of the mitotic spindle in the Rrp14p-depleted cells (Oeffinger et al. 2007).

Recent studies suggest that several bona fide regulatory factors of ribosome synthesis have functions in cell cycle (Shafaatian et al. 1996; Du and Stillman 2002; Zhang et al. 2002; Oeffinger and Tollervey 2003; Dosil and Bustelo 2004). Moreover, it was suggested that ribosome synthesis is related to cell size homeostasis (Jorgensen and Tyers 2004; Bernstein et al. 2007). We found for the first time that a regulatory factor of ribosome synthesis has an important role in the cell polarity derived from actin localization. Further work is necessary regarding how Rrp14p connects ribosome synthesis and the cell polarity. This will provide us with useful insights into the molecular mechanisms underlying the linkage between ribosome synthesis and cell division.

\section{MATERIALS AND METHODS}

\section{Plasmid construction}

pRS316-RRP14 was constructed as follows. A PCR fragment produced from yeast genomic DNA using the primers $5^{\prime}$ ATAACGTCGGAACCTAATAAGC-3' and 5'-GGATGTAATTG CCATCAGGTTT- $3^{\prime}$ was digested with SacI and ScaI, and inserted into the SacI and SmaI sites of pRS316. pRS314-GAL1-MYC-BS, a pRS314-based expression vector that contains the GAL1 promoter, the three myc epitopes-encoding region just downstream of the initiation codon, a multicloning site, and the TDH3 terminator, was kindly provided by K. Tanaka (Hokkaido University). pRS314-GAL1-MYC-RRP14 was constructed by inserting into pRS314-GAL1-MYC-BS with the BamHI-SmaI PCR fragment of the RRP14 ORF produced from yeast genomic DNA with the primers $5^{\prime}$-GGGGATCCAGTAATTCACTTGAGGAG-3', and 5'-GGCCCGGGTTATTTAGGTCCTCCCTT-3'. A plasmid expressing an myc-tagged Rrp14p by its own promoter, pRS314MYC-RRP14, was constructed as follows. The SacI-EcoRI (followed by blunt-ending) region of the GAL1 promoter of pRS314-GAL1-MYC-RRP14 was replaced with the SacI-SmaI PCR fragment of the RRP14 promoter produced from yeast genomic DNA with the primers 5' - GGGAGCTCGAAGAAAAAT GACGTGCCAA-3' and 5' - GGCCCGGGCTCAGTCTCCTATAT CTTTC-3'. For tagging N-terminal YFP, pRS304-YFP-RRP14 was created as follows. The SacI-EcoRI (followed by bluntending) region of the EBP2 promoter of pRS304-YFP-EBP2 was replaced with the SacI-SmaI PCR fragment of the RRP14 promoter produced as above, and the BamHI-SmaI region of the EBP2 ORF was replaced with the BamHI-SmaI PCR fragment of the RRP14 ORF as described above. pRS304-YFP-EBP2 was created by inserting it into pRS314-GAL1-MYC-BS with the BamHI-SmaI PCR fragment of the EBP2 ORF, replacing the $G A L 1$ promoter and $M Y C$ region with the EBP2 promoter and YFP produced from $\mathrm{pDH} 5$ (provided from The Yeast Resource Center, Seattle), respectively, and replacing the insert into pRS304. pRS316-NOP1-CFP expressing C-terminal CFP-tagged Nop1p was constructed as follows. The HindIII-SpeI fragment cleaved from YCplac33-NOP1-GFP (kindly provided by Y. Kikuchi, University of Tokyo) was inserted into the same sites of pRS315 to create pRS315-NOP1-GFP. pRS315-NOP1-CFP was created by replacing the PstI-SpeI GFP region of pRS315-NOP1GFP with the EcoT22I-SpeI CFP fragment amplified from a plasmid pDH3 (provided from The Yeast Resource Center, Seattle) with the primers $5^{\prime}$-TTTATGCATATGAAAGCAGAAGA ACTTTTC-3' and 5' -TCCACTAGTCTATTTGTATAGTTCATCC ATG-3'. The HindIII-SpeI fragment of pRS315-NOP1-CFP was inserted into pRS316 to create pRS316-NOP1-CFP.

\section{Gene disruption}

A deletion-insertion mutation of $R R P 14$ was constructed in the diploid W303 and BY4741. A primer pair, 5'-ATGAGTAATT 
CACTTGAGGAGCGCCTTCGTGCTAATTCAAGCGCCTTCGAT GGTTTATTGTTAAGAGCTTGGTGAGCGCTAGGA-3' and ' 5'ATGTCTTCCATATCGGAATCAGACGCAATTTCATCCTGATCC TGTTCCTGTTCACTTTCTCCTCGTTCAGAATGACACGTATAG3', which included sequences complementary to the RRP14 ORF, was used to PCR amplify the HIS3 sequence from plasmid pRS313. The resulting PCR product (containing the HIS3 ORF) was used to transform the W303 and BY4741 diploid cells. His ${ }^{+}$transformants were obtained and correct integration of the $\operatorname{rrp} 14: \because$ HIS3 gene at the homologous locus was confirmed by PCR. A correct integrant was sporulated and tetrads were dissected to obtain the $\operatorname{rrp} 14 \Delta$ strain.

\section{Yeast strains and media}

The yeast strains used were W303-1A (MATa ade2-1 can1-100 ura3-1 leu2-3,112 trp1-1 his3-11,15), W303-1B (MAT $\alpha$ ade2-1 can1-100 ura3-1 leu2-3,112 trp1-1 his3-11,15), KM1421 (W303$1 \mathrm{~B} \operatorname{rrp} 14 \because$ HIS3), KM1422 (W303-1A $\operatorname{rrp} 14 \therefore$ HIS3), KM1410 (W303-1A $\operatorname{rrp} 14 \because$ HIS3 pRS316-RRP14), KM1411 (W303-1A $\operatorname{rrp14} \because$ HIS3 pRS314-GAL1-MYC-RRP14), KM1412 (W303-1A $\operatorname{rrp14} \because$ HIS3 pRS314-MYC-RRP14), KM1419 (W303-1A rrp14 $\because$ HIS3 YFP-RRP14-TRP1 integrated at RRP14 pRS316-NOP1CFP), BY4741(MATa his3 leu2 met15 ura3), and KM1431 (BY4741 $\operatorname{rrp14} \because$ HIS3). KM1419 was constructed as follows. KM1410 was transformed with the EcoRI-digested DNA fragment of pRS304-YFP-RRP14, and transformants without pRS316RRP14 were selected on a plate containing $0.87 \mathrm{mg} / \mathrm{mL} 5$-fluoroorotic acid. Homologous recombination was checked by colony PCR and pRS316-NOP1-CFP was transformed. Yeast cells were grown in YPD-rich medium, synthetic complete (SC) medium containing $2 \%$ glucose (SC), or $2 \%$ galactose (SCGal), or SC dropout medium, depending on the plasmid markers.

\section{Polysome analysis}

Yeast crude cell extracts were overlaid on top of $11 \mathrm{~mL}$ of a $7 \%-$ $47 \%$ (wt/vol) sucrose gradient and centrifuged for $3.4 \mathrm{~h}$ at 35,000 $\mathrm{rpm}$ at $4^{\circ} \mathrm{C}$ in an Hitachi RPS40T rotor as previously described (Shirai et al. 2004). Gradients were collected by pumping up using a peristaltic pump and monitored at $254 \mathrm{~nm}$.

\section{[Methyl- ${ }^{3} \mathrm{H}$ ] methionine pulse-chase and Northern blot analyses}

Processing of pre-rRNA was analyzed by $\left[\right.$ methyl $\left.-{ }^{3} \mathrm{H}\right]$ methionine pulse chase as previously described (Miyoshi et al. 2001, 2003). Briefly, yeast cell cultures in SC-Met were pulsed with [methyl${ }^{3} \mathrm{H}$ ] methionine $(10 \mu \mathrm{Ci} / \mathrm{mL})$ for $3 \mathrm{~min}$ and were chased with nonradioactive methionine $(500 \mu \mathrm{g} / \mathrm{mL})$. Samples were taken by pouring cultures onto crushed sterile ice for preparing total RNA. Eight micrograms of total RNA were analyzed by electrophoresis and blotted to a Nytran membrane. The upper part of the membrane was sprayed with $\mathrm{En}^{3} \mathrm{Hance}$ (NEN) and exposed to film for $14 \mathrm{~d}$. The lower part of the membrane was probed for U3 snoRNA as a loading marker. For Northern blot analysis, the total RNA equivalent of $0.5 \mathrm{OD}_{600}$ or $1.5 \mathrm{OD}_{600}$ of cells was separated on an agarose gel or a denaturing $6 \%$ polyacrylamide/8 $\mathrm{M}$ urea gel, respectively, and transferred to a Nytran membrane by capillary or stained with ethidium bromide. Northern hybridization was carried out using ${ }^{32} \mathrm{P}$-labeled oligonucleotide probes.

\section{Run-on transcription analysis}

Yeast strains were grown in liquid YPD to an $\mathrm{OD}_{600}$ of $0.4-0.5$. Cells corresponding to $3.0 \mathrm{OD}_{600}$ units were harvested. Run-on transcription was performed according to the protocol of Elion and Warner (1986) with the following change: the cells were incubated with $\alpha-{ }^{32} \mathrm{P}-\mathrm{UTP}$ for $10 \mathrm{~min}$. Slot-blot hybridization was performed according to the protocol of Gallagher et al. (2004) with the following changes: PCR fragments were cloned into the pTOPO plasmid and spotted onto a Nitran membrane (Schleicher \& Schuell). Plasmids containing 5'ETS, 25S, and NTS of rDNA were kindly provided by Baserga and Gallagher (Yale University) (Gallagher et al. 2004). The sequences of the primers for the $5 \mathrm{~S}$ rRNA gene are $5^{\prime}$-CGGGATCCACCCATAACACCTCTCACTCCCA C- ${ }^{\prime}{ }^{\prime}$ and $5^{\prime}$-CGCTCGAGAGATTGCAGCACCTGAGTTTCGCG-3'.

\section{Two-hybrid system}

Two kinds of plasmid for production of lexA binding domainfusion proteins and Gal4p activation domain-fusion proteins were cotransformed into yeast L40 strain cells as previously described (Tsujii et al. 2000). $\mathrm{Leu}^{+} \mathrm{Trp}^{+}$transformants were selected and fivefold serial dilutions of the cell cultures were stamped on SCLeu, Trp, and His plates containing 3-amino-1, 2, and 4-triazole and incubated at $30^{\circ} \mathrm{C}$ for $3 \mathrm{~d}$ unless indicated.

\section{Western blotting}

Western blotting was performed following standard techniques, and signals were visualized by Enhanced Chemiluminescence (Amersham), as instructed by the manufacturer. Mouse antimyc monoclonal antibodies (9E10; BAbCO) and horseradish peroxidase-conjugated sheep antimouse IgG antibodies (NA931; Amersham) were used at 1:500 and 1:1000, respectively.

\section{Analysis of cell morphology}

The cells were cultured and stained with fluorescein isothiocyanate-Concanavalin A (FITC-ConA) for cell wall identification, with 4,6-diamidino-2-phenylindole (DAPI) to localize nuclei and with rhodamine-conjugated phalloidin to visualize the actin distribution following the CalMorph user manual with minor modification. Yeast cells were grown to the exponential phase $\left(4-6 \times 10^{6}\right.$ cells $\left./ \mathrm{mL}\right)$ at $30^{\circ} \mathrm{C}$. The cells were fixed for $30 \mathrm{~min}$ at $30^{\circ} \mathrm{C}$ in growth medium with formaldehyde (3.7\% final concentration) and potassium phosphate buffer (100 mM, pH 6.8). The cells were collected, resuspended in formaldehyde solution $(3.7 \%$ formaldehyde and $100 \mathrm{mM}$ potassium phosphate, $\mathrm{pH}$ 6.8), and incubated for $45 \mathrm{~min}$ at $30^{\circ} \mathrm{C}$. The cells were washed with PBS (137 mM NaCl, $2.68 \mathrm{mM} \mathrm{KCl}, 8.03 \mathrm{mM} \mathrm{Na}_{2} \mathrm{HPO}_{4}$, and $1.47 \mathrm{mM}$ $\mathrm{KH}_{2} \mathrm{PO}_{4}$ ) twice and stained with $20 \mathrm{U} / \mathrm{mL}$ rhodamine-phalloidin in PBS with $0.1 \%$ Triton $\mathrm{X}-100$ at $4^{\circ} \mathrm{C}$ overnight. The cells were washed with PBS and then with $\mathrm{P}$ buffer $(10 \mathrm{mM}$ sodium phosphate and $150 \mathrm{mM} \mathrm{NaCl}, \mathrm{pH} 7.2$ ), and stained with $24 \mu \mathrm{g} /$ $\mathrm{mL}$ FITC-ConA in $\mathrm{P}$ buffer for $5 \mathrm{~min}$ at room temperature. The 
cells were washed with $\mathrm{P}$ buffer and resuspended in P buffer. After a brief sonication, the cells were placed on slides, mounted with mounting solution $(1 \mathrm{mg} / \mathrm{mL}$-phenylenediamine, $0.1 \times \mathrm{PBS}$, $90 \%$ glycerol) containing $1 \mu \mathrm{g} / \mathrm{mL}$ DAPI, and observed under a fluorescence microscope (Olympus BX51) equipped with a $100 \times$ objective. All images were captured using a black-and-white charge-coupled device-coupled camera (Nippon Roper CoolSNAP HQ) and Slide Book 4 Digital Microscopy software (Intelligent Imaging Innovations). The data were processed with Adobe Photoshop and automatically analyzed with the CalMorph program.

\section{Analysis of budding patterns}

Yeast cells were cultured and sonicated for cell separation, and Calcofluor White was added to $2 \mu \mathrm{g} / \mathrm{mL}$ concentration. Bud scars were visualized by fluorescence microscopy and bud patterns were defined as described previously (Chant and Pringle 1995; Nelson et al. 2003). Only cells containing three or more bud scars were counted. Bud patterns were considered axial only if scars resided immediately adjacent to one another. Bud scars residing on opposite thirds of the cells were considered to be bipolar. Cells were considered to have random patterns if bud scars resided in the middle third of the cell.

\section{ACKNOWLEDGMENTS}

We thank R. Sternglanz, K. Tanaka, Y. Kikuchi, B. Ono, J.E.G. Gallagher, and S.J. Baserga, for yeast strains and/or plasmids. The CalMorph program has been provided freely by the University of Tokyo for use in this publication. This research was supported by Grants-in-Aid for Scientific research from the Japan Society for the Promotion of Science and from the Ministry of Education, Culture, Sports, Science, and Technology of Japan to K.M. C.H. and C.S. were supported by JSPS Research Fellowships for Young Scientists.

Received March 12, 2007; accepted August 2, 2007.

\section{REFERENCES}

Baladron, V., Ufano, S., Duenas, E., Martin-Cuadrado, A.B., del Rey, F., and Vazquez de Aldana, C.R. 2002. Englp, an endo-1,3- $\beta$ glucanase localized at the daughter side of the septum, is involved in cell separation in Saccharomyces cerevisiae. Eukaryot. Cell 1: 774-786.

Bassler, J., Grandi, P., Gadal, O., Lebmann, T., Petfalski, E., Tollervey, D., Lechner, J., and Hurt, E. 2001. Identification of a $60 \mathrm{~S}$ preribosomal particle that is closely linked to nuclear export. Mol. Cell 8: 517-529.

Bernstein, K.A., Bleichert, F., Bean, J.M., Cross, F.R., and Baserga, S.J. 2007. Ribosome biogenesis is sensed at the start cell cycle checkpoint. Mol. Biol. Cell 18: 953-964.

Bi, E. and Pringle, J.R. 1996. ZDS1 and ZDS2, genes whose products may regulate Cdc42p in Saccharomyces cerevisiae. Mol. Cell. Biol. 16: $5264-5275$.

Cabib, E., Roh, D.H., Schmidt, M., Crotti, L.B., and Varma, A. 2001. The yeast cell wall and septum as paradigms of cell growth and morphogenesis. J. Biol. Chem. 276: 19679-19682.

Chant, J. 1999. Cell polarity in yeast. Annu. Rev. Cell Dev. Biol. 15: 365-391.
Chant, J. and Pringle, J.R. 1995. Patterns of bud-site selection in the yeast Saccharomyces cerevisiae. J. Cell Biol. 129: 751-765.

Chen, G.C., Kim, Y.J., and Chan, C.S. 1997. The Cdc42 GTPaseassociated proteins Gic1 and Gic2 are required for polarized cell growth in Saccharomyces cerevisiae. Genes \& Dev. 11: 2958-2971.

Dosil, M. and Bustelo, X.R. 2004. Functional characterization of Pwp2, a WD family protein essential for the assembly of the $90 \mathrm{~S}$ pre-ribosomal particle. J. Biol. Chem. 279: 37385-37397.

Dragon, F., Gallagher, J.E.G., Compagnone-Post, P.A., Mitchell, B.M., Porwancher, K.A., Wehner, K.A., Wormsley, S., Settlage, R.E., Shabanowitz, J., Osheim, Y., et al. 2002. A large nucleolar U3 ribonucleoprotein required for $18 \mathrm{~S}$ ribosomal RNA biogenesis. Nature 417: 967-970.

Drees, B.L., Sundin, B., Brazeau, E., Caviston, J.P., Chen, G.C., Guo, W., Kozminski, K.G., Lau, M.W., Moskow, J.J., Tong, A., et al. 2001. A protein interaction map for cell polarity development. J. Cell Biol. 154: 549-571.

Du, Y.C. and Stillman, B. 2002. Yphlp, an ORC-interacting protein: Potential links between cell proliferation control, DNA replication, and ribosome biogenesis. Cell 109: 835-848.

Elion, E.A. and Warner, J.R. 1986. An RNA polymerase I enhancer in Saccharomyces cerevisiae. Mol. Cell. Biol. 6: 2089-2097.

Fatica, A., Cronshaw, A.D., Dlakic, M., and Tollervey, D. 2002. Ssflp prevents premature processing of an early pre-60S ribosomal particle. Mol. Cell 9: 341-351.

Gallagher, J.E.G., Dunbar, D.A., Granneman, S., Mitchell, B.M., Osheim, Y., Beyer, A.L., and Baserga, S.J. 2004. RNA polymerase I transcription and pre-rRNA processing are linked by specific SSU processome components. Genes \& Dev. 18: 2506-2517.

Grandi, P., Rybin, V., Baßler, J., Petfalski, E., Strauß, D., Marzioch, M., Schäfer, T., Kuster, B., Tschochner, H., Tollervey, D., et al. 2002. 90S pre-ribosomes include the $35 \mathrm{~S}$ pre-rRNA, the U3 snoRNP, and $40 \mathrm{~S}$ subunit processing factors but predominantly lack $60 \mathrm{~S}$ synthesis factors. Mol. Cell 10: $105-115$.

Hampichamchai, P., Jakovljevic, J., Horsey, E., Miles, T., Roman, J., Rout, M., Meagher, D., Imai, B., Guo, Y., Brame, C.J., et al. 2001. Composition and functional characterization of yeast $66 \mathrm{~S}$ ribosome assembly intermediates. Mol. Cell 8: 505-515.

Horsey, E.W., Jakovljevic, J., Miles, T.D., Harnpicharnchai, P., and Woolford Jr., J.L. 2004. Role of the yeast Rrp1 protein in the dynamics of pre-ribosome maturation. RNA 10: 813-827.

Jorgensen, P. and Tyers, M. 2004. How cells coordinate growth and division. Curr. Biol. 14: 1014-1027.

Kressler, D., Linder, P., and de la Cruz, J. 1999. Protein trans-acting factors involved in ribosome biogenesis in Saccharomyces cerevisiae. Mol. Cell. Biol. 19: 7897-7912.

Mager, W.H., Planta, R.J., Ballesta, J.-P.G., Lee, J.C., Mizuta, K., Suzuki, K., Warner, J.R., and Woolford Jr., J.L. 1997. A new nomenclature for the cytoplasmic ribosomal proteins of Saccharomyces cerevisiae. Nucleic Acids Res. 25: 4872-4875. doi: 10.1093/ nar/25.24.4872.

Magoulas, C. and Fried, M. 1996. The Surf- 6 gene of the mouse surfeit locus encodes a novel nucleolar protein. DNA Cell Biol. 15: 305-316.

Magoulas, C., Zatsepina, O.V., Jordan, P.W., Jordan, E.G., and Fried, M. 1998. The SURF-6 protein is a component of the nucleolar matrix and has a high binding capacity for nucleic acids in vitro. Eur. J. Cell Biol. 75: 174-183.

Miyoshi, K., Miyakawa, T., and Mizuta, K. 2001. Repression of rRNA synthesis due to a secretory defect requires the C-terminal silencing domain of Raplp in Saccharomyces cerevisiae. Nucleic Acids Res. 29: 3297-3303. doi: 10.1093/nar/29.16.3297.

Miyoshi, K., Shirai, C., and Mizuta, K. 2003. Transcription of genes encoding trans-acting factors required for rRNA maturation/ ribosomal subunit assembly is coordinately regulated with ribosomal protein genes and involves Rap1 in Saccharomyces cerevisiae. Nucleic Acids Res. 31: 1969-1973. doi: 10.1093/nar/gkg278. 
Mizuta, K. and Warner, J.R. 1994. Continued functioning of the secretory pathway is essential for ribosome synthesis. Mol. Cell. Biol. 14: 2493-2502.

Nelson, B., Kurischko, C., Horecka, J., Mody, M., Nair, P., Pratt, L., Zougman, A., McBroom, L.D., Hughes, T.R., Boone, C., et al. 2003. RAM: A conserved signaling network that regulates Ace2p transcriptional activity and polarized morphogenesis. Mol. Biol. Cell 14: 3782-3803.

Oeffinger, M. and Tollervey, D. 2003. Yeast Nop15p is an RNAbinding protein required for pre-rRNA processing and cytokinesis. EMBO J. 22: 6573-6583.

Oeffinger, M., Fatica, A., Rout, M.P., and Tollervey, D. 2007. Yeast Rrp $14 \mathrm{p}$ is required for ribosomal subunit synthesis and for correct positioning of the mitotic spindle during mitosis. Nucleic Acids Res. 35: 1354-1366. doi: 10.1093/nar/gkl 824.

Ohtani, M., Saka, A., Sano, F., Ohya, Y., and Morishita, S. 2004. Development of image processing program for yeast cell morphology. J. Bioinform. Comput. Biol. 1: 695-709.

Polzikov, M., Zatsepina, O., and Magoulas, C. 2005. Identification of an evolutionary conserved SURF-6 domain in a family of nucleolar proteins extending from human to yeast. Biochem. Biophys. Res. Commun. 327: 143-149.

Rempola, B., Karkusiewicz, I., Piekarska, I., and Rytka, J. 2006. Fcflp and Fcf2p are novel nucleolar Saccharomyces cerevisiae proteins involved in pre-rRNA processing. Biochem. Biophys. Res. Commun. 346: $546-554$

Saito, T.L., Ohtani, M., Sawai, H., Sano, F., Saka, A., Watanabe, D., Yukawa, M., Ohya, Y., and Morishita, S. 2004. SCMD: Saccharomyces cerevisiae morphological database. Nucleic Acids Res. 32: D319-D322. doi: 10.1093/nar/gkh113.

Saito, T., Sese, J., Nakatani, Y., Sano, F., Yukawa, M., Ohya, Y., and Morishita, S. 2005. Data mining tools for Saccharomyces cerevisiae morphological database. Nucleic Acids Res. 33: W753-W757. doi: 10.1093/nar/gki451.

Shafaatian, R., Payton, M.A., and Reid, J.D. 1996. PWP2, a member of the WD-repeat family of proteins, is an essential Saccharomyces cerevisiae gene involved in cell separation. Mol. Gen. Genet. 252: 101-114.

Shirai, C., Takai, T., Nariai, M., Horigome, C., and Mizuta, K. 2004. Ebp2p, the yeast homolog of Epstein-Barr virus nuclear antigen 1-binding protein 2, interacts with factors of both the 605 and 40S ribosomal subunit assembly. J. Biol. Chem. 279: 2535325358.

Titz, B., Thomas, S., Rajagopala, S.V., Chiba, T., Ito, T., and Uetz, P. 2006. Transcriptional activators in yeast. Nucleic Acids Res. 34: 955-967. doi: 10.1093/nar/gkj493.

Tschochner, H. and Hurt, E. 2003. Pre-ribosomes on the road from the nucleolus to the cytoplasm. Trends Cell Biol. 13: 255-263.

Tsujii, R., Miyoshi, K., Tsuno, A., Matsui, Y., Toh-e, A., Miyakawa, T., and Mizuta, K. 2000. Ebp2p, yeast homologue of a human protein that interacts with Epstein-Barr virus Nuclear Antigen 1, is required for pre-rRNA processing and ribosomal subunit assembly. Genes Cells 5: 543-553.

Tsuno, A., Miyoshi, K., Tsujii, R., Miyakawa, T., and Mizuta, K. 2000. $R R S 1$, a conserved essential gene, encodes a novel regulatory protein required for ribosome biogenesis in Saccharomyces cerevisiae. Mol. Cell. Biol. 20: 2066-2074.

Venema, J. and Tollervey, D. 1999. Ribosome synthesis in Saccharomyces cerevisiae. Annu. Rev. Genet. 33: 261-311.

Warner, J.R. 1999. The economics of ribosome biosynthesis in yeast. Trends Biochem. Sci. 24: 437-440.

Warner, J.R. 2001. Nascent ribosomes. Cell 107: 133-136.

Warner, J.R. and Udem, S.A. 1972. Temperature sensitive mutations affecting ribosome synthesis in Saccharomyces cerevisiae. J. Mol. Biol. 65: 243-257.

Winzeler, E.A., Shoemaker, D.D., Astromoff, A., Liang, H., Anderson, K., Andre, B., Bangham, R., Benito, R., Boeke, J.D., Bussey, H., et al. 1999. Functional characterization of the $S$. cerevisiae genome by gene deletion and parallel analysis. Science 285: 901-906.

Woolford Jr., J.L. and Warner, J.R. 1991. The ribosome and its synthesis. In The molecular and cellular biology of the yeast Saccharomyces: Genome dynamics, protein synthesis, and energetics (eds. J.R. Broach et al.), pp. 587-626. Cold Spring Harbor Laboratory Press, Cold Spring Harbor, NY.

Zhang, Y., Yu, Z., Fu, X., and Liang, C. 2002. Noc3p, a bHLH protein, plays an integral role in the initiation of DNA replication in budding yeast. Cell 109: 849-860. 

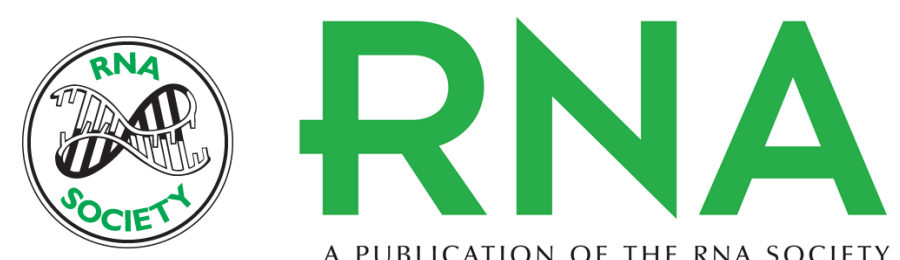

A PUBLICATION OF THE RNA SOCIETY

\section{Yeast Rrp14p is a nucleolar protein involved in both ribosome biogenesis and cell polarity}

Hiroko Yamada, Chihiro Horigome, Takafumi Okada, et al.

RNA 2007 13: 1977-1987 originally published online September 5, 2007

Access the most recent version at doi:10.1261/rna.553807

$\begin{array}{ll}\text { References } & \begin{array}{l}\text { This article cites } 46 \text { articles, } 18 \text { of which can be accessed free at: } \\ \text { http://rnajournal.cshlp.org/content/13/11/1977.full.html\#ref-list-1 }\end{array}\end{array}$

License

Email Alerting Receive free email alerts when new articles cite this article - sign up in the box at the Service top right corner of the article or click here.

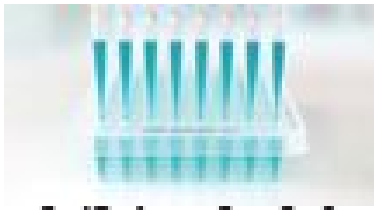

Providing Precise Solutions for your research.

To subscribe to RNA go to:

http://rnajournal.cshlp.org/subscriptions 